\title{
Mechanisms of Drug Resistance in Human Leukemia *
}

\author{
J. R. Bertino, S. Srimatkandada, M. D. Carman, E. Mini, M. Jastreboff, B. A. Moroson \\ and S. K. Dube
}

\section{A. Introduction}

Drug resistance remains a major obstacle to cure of patients with acute leukemia. At the present time, most centers are reporting $90 \%$ complete remission rates in acute lymphatic leukemia (ALL) and 70\%-80\% complete remission rates in patients with acute nonlymphocytic leukemia (ANLL). However, 5-year disease-free survival rates are only $50 \%$ and $10 \%-15 \%$, respectively, in these diseases. This is almost certainly due to the development of drug resistance even to the combination chemotherapy programs utilized to treat these diseases [1].

In this paper, we review the mechanisms by which cells become resistant to methotrexate (MTX) and strategies to eradicate selectively leukemic cells that have acquired resistance to the drug.

\section{B. Mechanisms of Acquired Resistance to MTX}

Methotrexate has been an excellent model drug for the study of acquired drug resistance. There is little metabolism of the drug intracellularly (except for polyglutamylation discussed below), the mechanism of action of the drug is well known [inhibition of the enzyme dihydrofolate reductase (DHFR)], and at least three and possibly

* Departments of Pharmacology and Medicine, Yale University School of Medicine, New Haven, CT 06510, USA

Supported by Grants CA 08010 and CA 08341 four different causes of acquired resistance to this drug have been observed. In addition very sensitive assays for DHFR enzyme activity have been developed, as well as mouse and human cDNA probes to detect gene amplification by sensitive "dotblot" techniques [2].

When cell lines or transplanted experimental tumors are exposed to MTX, and resistant cells emerge, resistance usually is due to one of two causes. These are either an increase in DHFR or a decreased uptake of MTX. Less commonly observed have been resistant sublines with an altered DHFR (reviewed in [4]) or a decrease in MTX polyglutamate formation [5].

\section{Increased Levels of DHFR as a Cause of MTX Resistance Gene Amplification}

Mouse, hamster, and human MTX-resistant cell lines have been described in recent years that have increased levels of DHFR (reviewed in [4]). When these lines have been examined with appropriate cDNA probes, in all cases gene amplification has been found to accompany the increase in DHFR level, as well as a corresponding increase in the level of mRNA(s) for this enzyme.

We have recently described three MTXresistant sublines obtained from human cells propagated in continuous culture with an increased level of DHFR: a lymphoblastic leukemia line (CEM-CCRF) [6], a blast-cell line (K562) [7], and a colon cancer cell line (HCT 8) (J. R. Bertino, unpublished observation). In all of these circum- 
Table 1. Dihydrofolate reductase activity and gene amplification in human cell lines resistant to MTX

\begin{tabular}{lcc}
\hline Cell line & $\begin{array}{l}\text { DHFR } \\
\text { enzyme } \\
\text { increase } \\
\text { (fold) }\end{array}$ & $\begin{array}{l}\text { DHFR gene } \\
\text { copy increase } \\
\text { (fold) }\end{array}$ \\
\hline CEM-CCRF $\left(\mathrm{R}_{1}\right)$ & 20 & 18 \\
K-562/MTX & 200 & 200 \\
HCT-8 $\left(\mathrm{R}_{1}\right)$ & 50 & 40 \\
\hline
\end{tabular}

stances, the increased level of DHFR was found to be associated with an increased level of DHFR gene copies (Table 1). Of interest is that two of these lines, CEMCCRF/R and HCT-8/R, when exposed to continued increased levels of MTX developed an additional transport defect for MTX or an altered DHFR, respectively (see below), presumably as a second mutational event in one of the amplified DHFR genes. When the chromosomes of these sublines with increased levels of DHFR were examined, the K562/MTX line showed a clearly demonstrable abnormal or homogeneous staining region (HSR) [7]. This cell line has three HSRs not found in the parent subline that have been identified as modified chromosomes \# 5, 6, and 19. This subline has remained stably resistant even in the absence of MTX for a period of 6 months. In general, this finding is in accord with previous reports that sublines resistant to MTX with a high level of stable resistance demonstrate a HSR, while cell lines with unstable resistance are associated with an increase in "double minute" chromosomes, i.e., small paired chromosomal bodies lacking a centromere [8].

The location of the unique DHFR gene in human cells has been reported to be on the \# 5 chromosome [9]: of interest is that another Burkitt's human cell line resistant to MTX was found also to have a large HSR in the \# 5 chromosome. However, another report of a $\mathrm{KB}$ human cell line also highly resistant to MTX contained an HSR in the \# 10 chromosome [10]. In situ hybridization with a human cDNA probe has not yet been reported with any of these cell lines, so it is likely, although unproven, that these HSRs are the site of the amplified DHFR genes.

The human DHFR gene $[7,11,12]$ has been reported to be very large (ca. $30 \mathrm{~kb}$ ), similar to the size reported for the mouse gene [13]. The availability of both mouse and human cDNA probes has allowed us to demonstrate that there is a significant sequence diversity in the noncoding $3^{\prime}$ end of the gene [7]. Chen et al. [12] and Masters et al. [11] have shown the presence in human DNAs of intronless DHFR genes or pseudogenes, which are nonfunctional [12]. Apparently these pseudogenes are not amplified in resistant cells; therefore they are easily missed in Southern blots from resistant-cell lines [12].

\section{Gene Amplification as a General Mechanism of Resistance to Anticancer Drugs}

Since the initial description of gene amplification as the mechanism by which mammalian cells become resistant to MTX, there have been several examples of gene amplification in cell lines resistant to other drugs (Table 2). Thus, it has become evident that this is a mechanism by which cells can increase the production of a target enzyme or receptor, thus resulting in a drugresistant phenotype. Although not demonstrated conclusively as yet, the multidrugresistant phenotype (cross-resistance to several natural product anticancer agents when resistance is developed to only one) may also be due to gene amplification.

\section{E. Gene Amplification in Patients with Leukemia Resistant to MTX}

Although gene amplification is commonly observed in MTX-resistant sublines, it was important to demonstrate that this event occurs in patients developing resistance to this drug. It was expected that a low level of amplification would be sufficient to cause MTX resistance, since the dose of MTX that can be safely administered is limited by toxic effects on normal tissues. In the three patients reported (two leukemia $[2,3]$ and one small-cell lung car- 
Table 2. Examples of gene amplification in drug-resistant sublines

\begin{tabular}{llll}
\hline Drug & Target enzyme or receptor increased & $\begin{array}{l}\text { Gene am- } \\
\text { plification }\end{array}$ & Ref. \\
\hline MTX & Dihydrofolate reductase & Yes & {$[16]$} \\
PALA & Aspartate transcarbamylase & Yes & {$[17]$} \\
$\mathrm{Ca}^{2+}$ & Metallothionein & Yes & {$[18]$} \\
Albizzin & Asparaginase synthase & Yes & {$[19]$} \\
5-Fluorodeoxyuridine & Thymidylate synthase & $(?)$ & {$[20]$} \\
Hydroxyurea & Ribonucleotide reductase & $(?)$ & {$[21]$} \\
$\begin{array}{l}\text { Deoxycoformycin } \\
\text { Colchicine (actinomycin D, } \\
\text { vinblastine, anthracyclines) }\end{array}$ & Adenosine deaminase & Yes & {$[22]$} \\
\hline
\end{tabular}

cinoma [22]), MTX resistance was found to be due to a low level of gene amplification (two- to fourfold). We are presently examining cells from additional leukemia patients thought to be clinically resistant to MTX in order to determine the frequency of this event as a mechanism of drug resistance to MTX. This will be of importance in regards to alternative treatment strategies (discussed below). We have found a rapid screening test for MTX resistance useful in determining whether resistance to MTX is present $\left(\left[{ }^{3} \mathrm{H}\right]\right.$ deoxyuridine incorporation into DNA in the absence and presence of MTX [23]).

\section{F. Altered DHFR as a Mechanism for MTX Resistance}

In experimental sublines propagated in vitro or in vivo, alteration of DHFR as a cause of MTX resistance is less commonly observed than is impaired transport or elevated DHFR [24]. Several lines have been reported, however, with altered DHFR enzymes, and one gene has been cloned, and the cDNA sequenced [25]. Table 3 lists the lines that have been described, and the alteration of enzyme activity observed in regards to MTX affinity. It should be pointed out, however, that most of these lines contain normal as well as altered genes, and unless the two enzymes are separated completely, the MTX-binding data may be misleading. We have recently obtained a cell line with an altered DHFR from the HCT-8/R line that also contained an elevated normal DHFR. This line contains an
Table 3. Examples of altered mammalian DHFR enzymes from MTX-resistant cells

\begin{tabular}{lcl}
\hline Source & $\begin{array}{l}\text { Decrease of } \\
\text { MTX/binding } \\
\text { to MTX (fold) }\end{array}$ & Ref. \\
\hline CH0 (hamster) & 4 & {$[31]$} \\
L1210 (mouse) & 10 & {$[30]$} \\
W1-L2 (human) & 50 & {$[32]$} \\
3T6 (mouse) & 270 & {$[27]$} \\
HCT-8 (human) & 100 & J. R. Bertino, \\
& & $\begin{array}{l}\text { unpublished } \\
\text { observation }\end{array}$ \\
L5178Y (mouse) & 100,000 & {$[29]$} \\
\hline
\end{tabular}

enzyme with a relatively high $V_{\max }$ as compared with the 3T6 MTX-resistant line. Thus we believe that a mutation at a different site(s) has occurred, as compared with the 3T6 mutation. Since it is believed that some 13 amino acids are involved in MTX binding to DHFR [26], it is possible that mutations affecting any of these binding sites may produce an altered DHFR.

These altered DHFR sublines have been extremely valuable as drug-selectable genes for DNA transfection studies, in particular the cDNA from the $3 \mathrm{~T} 6$ cell line that has been inserted into plasmid and retrovirus vectors $[25,27,28]$.

\section{G. MTX Resistance Due to Impaired Transport}

Impaired MTX transport, like increased DHFR enzyme activity, has been noted to be a relatively common mechanism of re- 
sistance to this antifolate. In one study of drug resistance produced in vivo to cells in mice, impaired transport was as commonly noted as elevated DHFR as the cause of MTX resistance [24]. Little is known about the molecular nature of this resistance, which involves the carrier transport system present for the active transport for reduced folates (5-methyltetrahydrofolate, 5-formyl tetrahydrofolate). While this could also be an example of gene amplification, there was no cross-resistance to other antitumor agents noted when a CEM-CCRF transport mutant subline was tested [33]. Thus far, the mammalian transport system for reduced folates and MTX has not been isolated or characterized, but these resistant sublines may allow an approach to this problem.

\section{H. Eradication of Drug-Resistant Cells}

Although the probability of drug resistance occurring to MTX may be decreased with the use of drug combinations, this possibility is limited for the treatment of many human malignancies because of the lack of useful agents for treatment. Also, the addition of alkylating agents to combination regimens may increase the probability of mutations leading to MTX resistance in surviving cells. Of great potential importance is the recent work of Schimke et al., which suggests that gene amplification may be facilitated by agents that interrupt DNA synthesis early in S-phase [34]. Strategies to eradicate MTX-drug-resistant cells have been suggested by us as well as by others [35-38]. A general approach involves the use of high specific activity $\left[{ }^{3} \mathrm{H}\right]$ deoxyuridine in the presence of MTX and hypoxanthine and thymidine [35]. This combination would be lethal for MTX-resistant cells, since MTX would not block $\left[{ }^{3} \mathrm{H}\right]$ deoxyuridine incorporation into DNA, while in sensitive cells it would. This approach works in vitro, but will probably be impractical for in vivo use.

We have recently utilized a new inhibitor of DHFR, trimetrexate (TMQ) [39], to treat MTX-resistant cells [33]. Trimetrexate or other folate antagonists that accumulate in cells to high levels and do not use the folate
Table 4. Effect of MTX and TMQ on the parenteral CCRF-CEM lymphoblastic leukemia cell line and two resistant sublines. The CCRF$\mathrm{CEM} / \mathrm{R}_{1}$ line has a 20 -fold increase in DHFR activity, while the $R_{3}$ line has normal DHFR activity, but has a markedly impaired uptake of MTX [33]

\begin{tabular}{lcc}
\hline Cell line & $\begin{array}{l}\mathrm{ED}_{50} \mathrm{MTX} \\
(\mathrm{n} M)\end{array}$ & $\begin{array}{l}\mathrm{ED}_{50} \mathrm{TMQ} \\
(\mathrm{n} M)\end{array}$ \\
\hline $\begin{array}{l}\text { CCRF-CEM } \\
\text { (parent) }\end{array}$ & 15 & 5 \\
CCRF-CEM/R & 1500 & 150 \\
CCRF-CEM/R & 3400 & 3 \\
\hline
\end{tabular}

transport system may be effective agents against MTX-resistant cells with impaired transport or low levels of DHFR gene amplification [33, 34]. Table 4 indicates that trimetrexate is highly effective in a MTXtransport-resistant CCRF-CEM cell line (R3); and more effective than MTX in a CCRF-CEM cell line, with a 20-fold increase in DHFR (R1). In the $3 T 6$ cell line resistant to MTX because of an altered DHFR, trimetrexate also has a markedly decreased affinity for the enzyme and thus would be of no value in the treatment of cells resistant by this mechanism [27]. We are currently attempting to look for inhibitors that would be effective against cells with an altered DHFR; selective inhibition may be possible in this circumstance.

We are testing these strategies by employing combinations of antifolates that presumably would limit the emergence of drug-resistant cells, e.g., concomitant MTX and trimetrexate treatment versus sequential uses of these agents.

\section{References}

1. Gunz FW, Henderson ES (eds) (1983) Leukemia. Grune and Stratton, New York

2. Horns RC, Dower WJ, Schimke RT (1984) Gene amplification in a leukemia patient treated with methotrexate. J Clin Oncol $2: 2-7$

3. Carman MD, Schornagel JH, Rivest RS, Srimatkandada S, Portlock CS, Bertino JR (1984) Resistance to methotrexate due to gene amplification in a patient with acute leukemia. J Clin Oncol 2:16-20 
4. Bertino JR, Srimatkandada S, Carman MD, Schornagel JH, Medina W, Moroson BA, Cashmore AR, Weiner HL, Dube SK (1983) Mechanism of methotrexate in acute leukemia. Normal and neoplastic hematopoiesis. Liss, New York, pp 465-478

5. Cowan KH, Jolivet J (1984) A methotrexate resistant human breast cancer cell line with multiple defects, including diminished formation of methotrexate polyglutamates. $J$ Biol Chem 259: 10 798-10 800

6. Mini E, Srimatkandada S, Medina WD, Moroson BA, Carman MD, Bertino JR (1985) Molecular and karyological analysis of methotrexate-resistant and sensitive human leukemic CCRF-CEM cells. Cancer Res. 45, 317-324

7. Srimatkandada S, Medina WD, Cashmore AR, Whyte W, Engel D, Moroson BA, Franco CT, Dube S, Bertino JR (1983) Amplification and organization of dihydrofolate reductase genes in a human leukemic cell line, K562, resistant to methotrexate. Biochemistry 22:5774-5781

8. Kaufman RJ, Brown PC, Schimke RT (1979) Amplified dihydrofolate reductase genes in unstably methotrexate-resistant cells are associated with double minute chromosomes. Proc Nat Acad Sci USA 76:5669-5673

9. Anagou NP, O'Brien SJ, Shimada T, Nash WG, Chen MJ, Nienhuis AW (1984) Chromosomal organization of the human dihydrofolate reductase genes: dispersion, selective amplification, and a novel form of polymorphism. Proc Natl Acad Sci USA 81:5170 $-5174$

10. Wolman SR, Craven ML, Grill SP, Domin BA, Cheng Y-C (1983) Quantitative correlation of homogeneously stained regions on chromosome 10 with dihydrofolate reductase enzyme in human cells. Proc Natl Acad Sci USA 80:807-809

11. Masters JN, Yank JR, Celini A, Attardi GJ (1983) A human dihydrofolate reductase pseudogene and its relationship to the multiple forms of specific messenger RNA

12. Chen MJ, Shimada T, Moneton AD, Cline A, Humphries RK, Maizel J, Nienhuis AW (1984) The functional human dihydrofolate reductase gene. J Biol Chem 259:3933-3943

13. Crouse GF, Simonsen CC, McEwan RN, Schimke RT (1982) Structure of amplified normal and variant dihydrofolate reductase genes in mouse sarcoma S180 cells. J Biol Chem 257:7887-7898

14. Alt FW, Kellems RE, Bertino JR, Schimke RT (1978) Selective multiplication of dihydrofolate reductase genes in methotrexateresistant variants of cultured murine cells. $\mathbf{J}$ Biol Chem 253: 1357-1370
15. Wahl GM, Padgett RA, Stark GR (1979) Gene amplification causes overproduction of the first three enzymes of UMP synthesis in PALA $N$-(phosphoroacetyl)-L-asparate-resistant hamster cells. J Biol Chem 254:8679 $-8869$

16. Beach LR, Palmiter RD (1981) Amplification of the metallothionein-I gene in cadmium-resistant mouse cells. Proc Natl Acad Sci USA 78:2110-2114

17. Anarulis IL, Duff C, Evans-Blacker S et al. (1983) Chromosomal alterations associated with overproduction of asparagine synthetase in Albizzin-resistant Chinese hamster ovary cells. Mol Cell Biol 3:391-398

18. Rossana C, Rao LG, Johnson LF (1982) Thymidylate synthetase overproduction in 5-fluorodeoxyuridine-resistant mouse fibroblasts. Mol Cell Biol 2: 1031-1037

19. Lewis WH, Wright JA (1979) Isolation of hydroxyurea-resistant $\mathrm{CHO}$ cells with altered levels of ribonucleotide reductase. Somatic Cell Genet 5:83-96

20. Yeung C-Y, Ingolia DE, Bobonis C, Dunbar BS, Riser ME, Siciliano MJ, Kellems RE (1983) Selective overproduction of adenosine deaminase in cultured mouse cells. J Biol Chem 258:8338-8345

21. Riordan JR, Ling V (1979) Purification of P. glycoprotein from plasma membrane vesicles of Chinese hamster ovary cell mutants with reduced colchine permeability. J Biol Chem 254: 12 701-12 705

22. Curt GA, Carney DN, Cowan KH, Jolivet J, Bailey BD, Drake JC, Kao-shan CS, Minna JD, Chabner BA (1983) N Engl J Med 308: 199-202

23. Bertino JR, Skeel RT (1975) On natural and acquired resistance to folate antagonists in man. In: pharmacological basis of cancer chemotherapy. Williams and Wilkins, Baltimore, pp 681-689

24. Sirotnak FM, Moccio DM, Kelleher LE, Goutas LJ (1981) Relative frequency and kinetic properties of transport defective phenotypes among methotrexate-resistant L1210 clonal cells derived in vivo. Cancer Res 41:4447-4452

25. Simonsen CC, Levinson AD (1983) Isolation and expression of an altered mouse dihydrofolate reductase cDNA. Proc Natl Acad Sci USA 80:2495-2499

26. Vol KW, Matthews DA, Alden RA, Freer ST, Hansch C, Kaufman T, Kraut J, Crystal structure of avian dihydrofolate reductase containing phenyltriazine and NADPH. J Biol Chem 257:2528-2536

27. Haber DA, Beverly SM, Kiely ML, Schimke RT (1981) Properties of an altered dihydrofolate reductase encoded by amplified 
genes in cultured mouse fibroblasts. J Biol Chem 256:9501-9510

28. Kaufman R, Sharp P (1982) Construction of a modular dihydrofolate reductase cDNA gene: analysis of signals utilized for efficient expression. Mol Cell Biol 2:1304-1309

29. Goldie JH, Krystal G, Hartley D, Gudauskas G, Dedhar S (1980) A methotrexate insensitive variant of folate reductase present in two lines of methotrexate-resistant L5178Y cells. Eur J Cancer 16: 1539-1546

30. Duffy TH, Beckman SB, Huennekens FM (1984) Forms of L1210 dihydrofolate reductase differing in affinity for methotrexate. Fed Proc 43:3436 (abstract)

31. Flintoff WF, Essani K (1980) Methotrexateresistant Chinese hamster ovary cells contain a dihydrofolate reductase with an altered affinity for methotrexate. Biochem J 19:4321 $-4327$

32. Niethammer D, Jackson RC (1975) Changes of molecular properties associated with the development of resistance against methotrexate in human lymphoblastoid cells. Eur $\mathbf{J}$ Cancer 4:845-854

33. Mini E, Moroson BA, Franco CT, Bertino JR (1985) Cytotoxic effects of folate antagonists against methotrexate-resistant human leukemia lymphoblast CCRF-CEM cell lines. Cancer Res 45, 325-330
34. Kamen BA, Eibl B, Cashmore AR, Bertino JR (1984) Uptake and efficacy of trimetrexate, a non-classical antifolate in methotrexate-resistant leukemia cells in vitro. Biochem Pharmacol 33:1697-1699

35. Urlaub G, Landzberg M, Chasin LA (1981) Selective killing of methotrexate-resistant cells carrying amplified dihydrofolate reductase genes. Cancer Res 41:1594-1601

36. Bertino JR (1979) Toward improved selectivity in cancer chemotherapy: The Richard and Hinda Rosenthal Foundation Award Lecture. Cancer Res 39:293-304

37. Ryser HJ, Shen WC (1980) Conjugation of methotrexate to poly (l-lysine) as a potential way to overcome drug resistance. Cancer 45: 1207-1211

38. Hill BT, Price LA, Harrison SI, Gredi JH (1977) The difference between "selective" folinic acid rescue in 5178Y cell culture. Eur J Cancer 13:861-871

39. Bertino JR, Sawicki WL, Moroson BA, Cashmore AR, Elslager EF (1979) 2,4-diamino5-methyl-6 [3,4,5-trimethoxyanilino)methyl] quinazoline (TMQ). A potent non-classical folate antagonist inhibitor-I. Biochem Pharmacol 28: 1983-1987

40. Schimke RT (1984) Gene amplifacication in cultured animal cells. Cell 37:705-713 